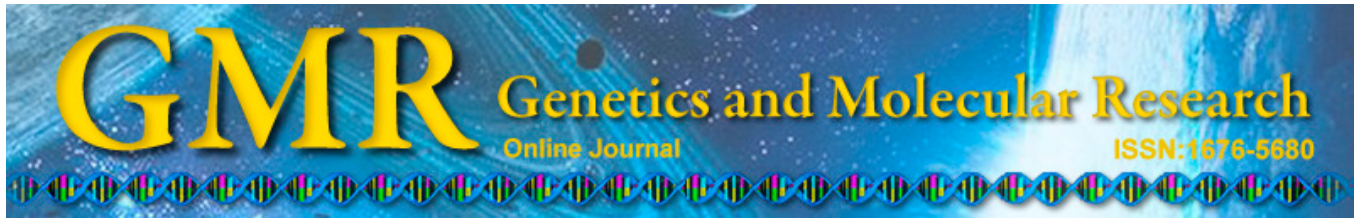

\title{
Associations between genetic variants in the promoter region of the insulin-like growth factor-1 (IGF1) gene and blood serum IGF1 concentration in Hanwoo cattle
}

\author{
H.Y. Chung ${ }^{1}$, Y.J. Choi ${ }^{1}$, H.N. Park ${ }^{1}$ and M.E. Davis ${ }^{2}$ \\ ${ }^{1}$ Animal Genomics and Bioinformatics Division, \\ National Institute of Animal Science, Suwon, Korea \\ ${ }^{2}$ Department of Animal Sciences, Ohio State University, Columbus, OH, USA \\ Corresponding author: H.Y. Chung \\ E-mail: chung133@korea.kr
}

Genet. Mol. Res. 14 (2): 3026-3035 (2015)

Received May 7, 2014

Accepted September 25, 2014

Published April 10, 2015

DOI http://dx.doi.org/10.4238/2015.April.10.13

\begin{abstract}
In this study, we investigated the associations between genetic variants in the promoter region of the insulin-like growth factor-1 (IGF1) gene and blood serum IGF1 concentration in Hanwoo cattle. Polymerase chain reaction primers were based on GenBank accession No. AF404761 and amplified approximately 533-bp segments. Newly identified sequences were submitted to GenBank (accession No. DQ267493). Sequence analysis revealed that genetic variants were located at a nucleotide position 323 for the nucleotide substitution $\mathrm{C} / \mathrm{A}$ that was first reported in this study and positions 326-349 for a repeat motif $\left(\mathrm{CA}_{10-11}\right)$. The allele frequencies of $\mathrm{g} .323 \mathrm{C}>\mathrm{A}$ were 0.264 (C) and 0.736 (A) without significant deviation from Hardy-Weinberg equilibrium. Frequencies of the repeat motif $\mathrm{CA}_{(10)}$ and $\mathrm{CA}_{(11)}$ were 0.604 and 0.396, respectively. Statistical analysis revealed that the genetic variation g.323C $>$ A was significantly associated with blood serum IGF1 concentrations with significant additive genetic effects, whereas no
\end{abstract}


associations were found for the repeat motif. $I G F 1$ concentrations were positively $(\mathrm{r}=0.453)$ and negatively $(\mathrm{r}=-0.445)$ correlated with weights in the growing stages (16-21 months) and late fattening stages (22-30 months), respectively. The results of the present study and future genotypic data for Hanwoo beef cattle based on the robust genetic variation of IGF1 will provide critical information for genetic improvement and will have a large impact on commercial markets.

Key words: Hanwoo cattle; IGF1 concentration; Polymorphism

\section{INTRODUCTION}

Insulin-like growth factor-1 (IGF1), which is mainly synthesized and secreted by the liver, is a $7.5-\mathrm{kDa}$ single-chain polypeptide containing 6 exons and regulates growth, cell development, and differentiation. In addition, $I G F 1$, in complex with several $I G F$ binding proteins, mediates the effects of growth hormones (Rosen and Pollak, 1999). Therefore, both growth hormones and IGF1 play critical roles in mammary gland development, growth, and fertility as major regulators of postnatal growth and metabolism (Lucy, 2008).

Because $I G F 1$ concentration is relatively stable in the blood as a result of its long biological cycles (Breier et al., 1988), measurement of IGFI can be used to determine activity levels for the somatotrophic axis as a main component in the chemical communication network and is valuable for understanding the biological nature of animals (Staniar et al., 2007). However, several factors such as breed, age, sex, and nutritional status influence serum IGFI concentrations (Davis and Simmen, 1997).

Because of the significant relationships between animal growth and serum $I G F 1$ concentrations, studies have shown that $I G F 1$ is reflective of growth traits (Davis and Simmen, 1997; Ge et al., 2001). Furthermore, recent studies reported that IGFI is a promising candidate genetic marker for improving growth and production traits of dairy cattle based on its association with milk fat and proteins (Bonakdar et al., 2010; Mullen et al., 2011). In addition, utilization of $I G F 1$ as a physiological indicator may change the genetic structures of domestic populations to maximize selection intensities and increase the accuracy of selection in cattle, swine, sheep, and chickens (Goddard et al., 1988; Roberts et al., 1990; Spicer et al., 1992). Although previous studies have shown that genetic variants of the $I G F 1$ gene significantly influence several quantitative traits such as growth (Ge et al., 2001; Reyna et al., 2010), milk production (Bonakdar et al., 2010; Mullen et al., 2011), carcass traits (Akis et al., 2010), and rate of gain (Anderson et al., 1988), little is known regarding the relationships between genetic variants in the $I G F 1$ gene and serum concentrations of $I G F 1$. The objective of this study was to confirm that genetic polymorphisms in the $I G F 1$ gene are associated with serum $I G F 1$ concentrations in beef cattle. In addition, we examined the relationships between $I G F 1$ concentration and growth to determine changes in IGFI concentration with age.

\section{MATERIAL AND METHODS}

\section{Animals}

The procedures followed in this study were approved by the animal care and Ethics 
Committee of the National Institute of Animal Science (NIAS), Korea. In this study, we used 412 Hanwoo steers raised under a standardized management program involving the castration of bulls at 3 months of age and feeding an ad libitum diet consisting of roughage and concentrates at $1.5 \%$ of body weight. Pedigree analysis revealed no significant relationships between individuals, showing less than 0.01 inbreeding coefficients, with animal ages from 13-31 months. Diets were formulated to meet National Research Council (NRC, 2000) requirements for growing beef cattle. The feed supply was restricted for $12 \mathrm{~h}$ after $6: 00 \mathrm{pm}$ on day 1 before blood collection, and approximately $10 \mathrm{~mL}$ blood was collected from the jugular vein at 6:00 am on day 2. The second sampling was repeated 7 days later to minimize total variations in measurements with the same feed restrictions before the second blood sampling. A total of 397 individuals were further analyzed, with some cattle removed from analysis because of missing tags or errors in measurements.

\section{Sample preparation}

Approximately, $9 \mathrm{~mL}$ blood was allowed to clot for $24 \mathrm{~h}$ at room temperature and the serum was obtained by centrifugation $(1800 \mathrm{~g}$ for $20 \mathrm{~min})$ and frozen at $-70^{\circ} \mathrm{C}$ until analysis. A radioimmunoassay was conducted to measure concentrations of $I G F 1$ with a Coat-ACount kit (Cruinn Diagnostic Limited, Dublin, Ireland) using a gamma $(\gamma)$-counter (Cobra II, Packard Bioscience, Meriden, CT, USA) according to manufacturer instructions. The intraassay coefficient of variation was $3.2 \%$.

DNA was extracted from $200 \mu \mathrm{L}$ whole blood using a proteinase K/salting out/ethanol precipitation method, and the quality and quantity of DNA were assessed using a Nanodrop spectrophotometer (Thermo Scientific, Waltham, MA, USA) and agarose gel electrophoresis. DNA was suspended in distilled water until genotyping and sequence analyses.

\section{Polymerase chain reaction (PCR)}

The primer sequences were selected from the 5'-untranslated region based on the sequence (GenBank accession No. AF404761), and forward and reverse primers were ACCCC AGGAA AAGTG GGATG T (nucleotides 527-547) and AAATC TTTGC CCTGT CGTGG (1036-1055), respectively. The optimal size of PCR fragments in this analysis was approximately $500 \mathrm{bp}$ using the PrimerSelect program of DNAstar version 6.0, using options for an optimal $\mathrm{Tm}\left(57^{\circ} \mathrm{C}\right)$ and $60 \% \mathrm{GC}$ content.

Two microliters 10X reaction buffer $(10 \mathrm{mM}$ Tris, $\mathrm{pH} 8.3,50 \mathrm{mM} \mathrm{KCl}, 0.1 \%$ Triton $\mathrm{X}-100,1.5 \mathrm{mM} \mathrm{MgCl}$ ), $2.5 \mathrm{mM}$ dNTPs, $10 \mathrm{pM}$ of each primer, $50 \mathrm{ng}$ genomic DNA, and $1 \mathrm{U}$ Taq DNA polymerase (Gibco BRL, Grand Island, NY, USA) in a final volume of $20 \mu \mathrm{L}$ were used. After heating the samples at $95^{\circ} \mathrm{C}$ for $4 \mathrm{~min}$, a total of 35 cycles included for denaturation at $94^{\circ} \mathrm{C} / 1 \mathrm{~min}$, annealing at $57^{\circ} \mathrm{C} / 1 \mathrm{~min}$, and extension at $72^{\circ} \mathrm{C} / 1.5 \mathrm{~min}(\mathrm{PT}-200$, MJ Research, Waltham, MA, USA). After confirmation of amplification using 1.2\% agarose gels, PCR products were purified using DNA purification kits (Nucleogen, Ansan, Korea), and direct sequencing analysis for individual DNA samples using an ABI3730 XL Genetic Analyzer (Applied Biosystems, Foster City, CA, USA) verified the genetic variations. Verification of sequences and alignments determined single nucleotide polymorphisms (SNPs), as well as repeat units, using the SEQMAN program of DNAstar version 6.0. 


\section{Statistical analysis}

Analysis of variance was conducted using the Statistical Analysis System (SAS, Cary, NC, USA) with a general linear model procedure to investigate the effects of genotypes on $I G F 1$ concentration. Least squares means and standard errors for each trait were estimated using a linear model as follows: $Y_{i j k}=\mu+S_{i}+\beta A_{j}+G_{k}+e_{i j k}$, where $\mathrm{Y}_{i j k}$ is the observation of traits, $\mu$ is the overall mean for each trait, $S_{i}$ is the random effect of sire, $A_{j}$ is the effect of age as a covariate, $G_{k}$ is the fixed effect of genotype, and $\mathrm{e}_{i j k}$ is random residual error. Where significant associations were identified, mean values for each genotype were compared using the Tukey studentized range procedure with a comparison error rate of 0.05 . Additive and dominance genetic effects and correlations were estimated using SAS with options of contrast and correlations. Allele frequencies and Hardy-Weinberg equilibrium were estimated using Arlequin version 3.1. Comparisons of putative binding sites for transcription factors according to nucleotide substitutions were carried out using a web-based program TFBLAST (http:// www.transcriptionfactor.org).

\section{RESULTS}

\section{Genetic variation}

After sequence alignment, the identified sequences of IGF1, which contained the SNP and CA nucleotide repeat units (Figure 1), were submitted to GenBank (accession No. DQ267493). Sequence analyses revealed that the identified genetic variants were located at nucleotide positions 323 for the SNP and from 327-348 for the repeat unit in the promoter region based on sequences of DQ267493. These nucleotide positions corresponded to nucleotide positions at -977 for the SNP and -973 to 953 for the repeat units from the starting codon based on the complete sequence of the $I G F 1$ gene (AF210383). As shown in Table 1, allele frequencies of the SNP were estimated to be 0.736 and 0.264 for alleles A and C, respectively, without significant deviations from the Hardy-Weinberg equilibrium. The frequencies of genotypes for the repeat unit were estimated to be 0.396 and 0.604 for $\mathrm{CA}_{(11)}$ and $\mathrm{CA}_{(10)}$, respectively. Comparisons of putative binding sites for transcription factors confirmed that alleles $\mathrm{A}$ and $\mathrm{C}$ showed relatively low identification rates with homeobox genes such as HOXD8 (T01426) and HOXA4 (T01701), presenting no significantly different binding sites with both the SNP and repeat units according to the nucleotide substitutions.
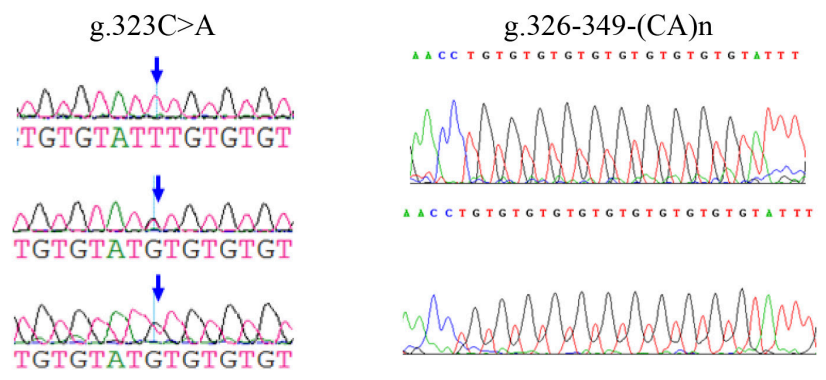

Figure 1. Identification of genetic variants for the SNP g.323C $>$ A and repeat motif g.326-349(CA)n by using sequencing analysis with ABI 3730 XL Genetic Analyzer for Hanwoo cattle. 
Table 1. Least squares means and standard errors of $I G F 1$ concentrations by $I G F 1$ genotypes.

\begin{tabular}{|c|c|c|c|c|c|c|c|c|c|}
\hline \multirow[t]{2}{*}{ Locus } & \multicolumn{4}{|c|}{ Variations of $I G F I$} & \multicolumn{2}{|c|}{ Distribution } & \multicolumn{3}{|c|}{ Genetic effects } \\
\hline & Genotype & $\mathrm{N}$ & Concentration & Pvalue & Allele & Frequency & Effect & Estimate & Pvalue \\
\hline \multirow[t]{3}{*}{$\overline{\mathrm{SNP}^{1}}$} & AA & 216 & $321.601 \pm 11.92^{\mathrm{a}}$ & \multirow{3}{*}{0.0008} & A & 0.736 & Additive & $72.770 \pm 34.88$ & 0.0391 \\
\hline & $\mathrm{AC}$ & 153 & $389.842 \pm 14.34^{\mathrm{b}}$ & & $\mathrm{C}$ & 0.264 & \multirow[t]{2}{*}{ Dominance } & \multirow[t]{2}{*}{$-4.531 \pm 35.78$} & \multirow[t]{2}{*}{0.8994} \\
\hline & $\mathrm{CC}$ & 28 & $394.372 \pm 34.78^{\mathrm{b}}$ & & & & & & \\
\hline \multirow[t]{2}{*}{$\mathrm{CA}^{2}$} & 10 & 240 & $351.575 \pm 11.68$ & \multirow[t]{2}{*}{0.8679} & $\mathrm{CA}_{(10)}$ & 0.604 & \multirow[t]{2}{*}{ Additive } & \multirow[t]{2}{*}{$-4.895 \pm 20.08$} & \multirow[t]{2}{*}{0.8080} \\
\hline & 11 & 156 & $354.808 \pm 15.48$ & & $\mathrm{CA}_{(11)}$ & 0.396 & & & \\
\hline
\end{tabular}

1,2The genetic variations for the SNP and repeat unit were located in nucleotide position 323 and from 350-360, respectively. IGFl concentrations are reported in $\mathrm{ng} / \mathrm{mL}$. Data are reported as means $\pm \mathrm{SE}$. Different superscript letters mean significant differences.

\section{IGF1 concentration}

The descriptive summary for measurements of $I G F 1$ concentration is presented for normality, means, standard errors, and minimum and maximum values (Table 2). Concentrations varied depending on age, and there was a significant difference between the lowest $(249.76 \mathrm{ng} / \mathrm{mL})$ and highest average concentrations $(432.32 \mathrm{ng} / \mathrm{mL})$ by age as shown in Figure 2. Overall IGF1 concentrations generally increased according to stage of growth from 13-21 months (Stage I), while decreasing patterns were observed from 22-31 months of age (Stage II). Before approximately 21 months of age, IGF1 concentration rapidly increased as the animals reached full size, whereas the concentration continuously decreased after approximately 21 months of age, which may be a conversion point of IGFI secretion. Stages I and II showed significant positive $(\mathrm{r}=0.453, \mathrm{P}=0.0065)$ and negative $(\mathrm{r}=-0.445, \mathrm{P}=0.0012)$ correlations with blood serum $I G F 1$ concentrations.

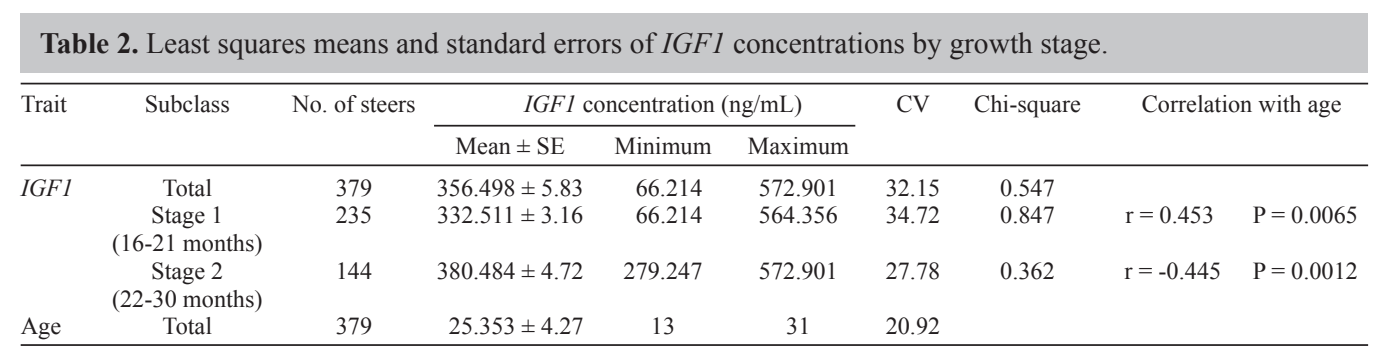

$I G F 1=$ insulin-like growth factor-1. $\mathrm{CV}=$ coefficient of variation. Chi-square $=$ chi-square probability for the normality of measurements. Age is reported in months.

\section{Genetic association}

Animals with genotypes CC (394.372 ng/mL) and AC (389.842 ng/mL) showed significantly greater $I G F 1$ concentrations than animals with genotype AA $(321.601 \mathrm{ng} / \mathrm{mL})$, whereas significant differences were not detected using the CA repeat. In addition, a significant additive genetic effect was estimated using the SNP, whereas significant genetic effects were not observed with repeat units. Therefore, animals with allele $\mathrm{C}$ were expected to show higher IGF1 concentrations than animals having allele A, which may be useful for selection programs designed to change genetic properties of target populations. 


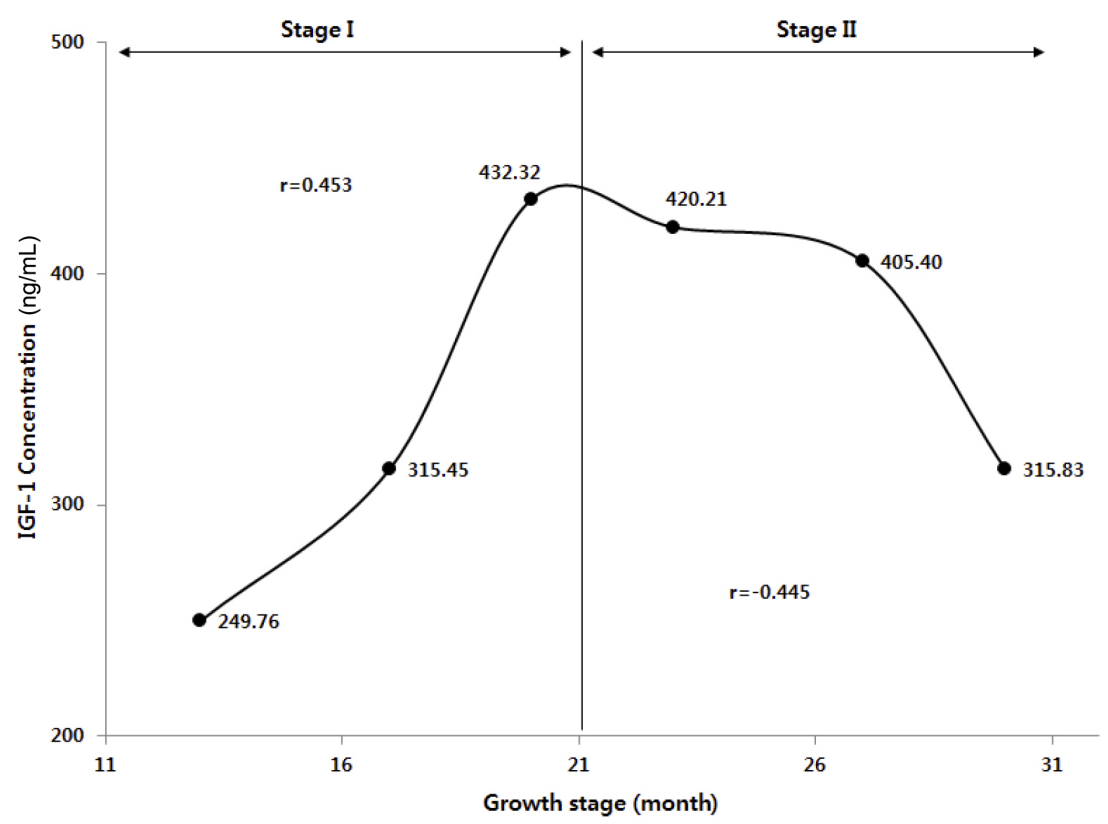

Figure 2. Distribution of $I G F 1$ concentrations according to the stage of growth. The $I G F-1$ concentrations and age are reported in $\mathrm{ng} / \mathrm{mL}$ and months, respectively. A total of 378 animals were used, and the numbers of animals for each stage were as follows: 34 (M13), 92 (M17), 55 (M20), 75 (M23), 48 (M27), and 74 (M30).

\section{DISCUSSION}

\section{Blood serum IGF1 concentration}

In agreement with the changing patterns of $I G F 1$ concentrations according to growth stages described in this analysis, several reports indicated that blood serum IGFI concentration increases according to animal growth as $I G F 1$ directly mediates the effects of growth hormones (Wang et al., 1999). Similar results have been reported showing that IGFI concentration increased continuously from birth to a certain point of growth and then decreased significantly in older mares, foals, and thoroughbreds (Malinowski et al., 1996; Fortier et al., 2005). These studies suggested that serum IGFI concentration increased in neonates, after which it either remained relatively stable to a certain age or decreased. Therefore, IGF1 concentrations increase from birth to approximately 28 months of age in Hanwoo cattle to fulfill growth requirements and then begin to decline. The results also imply that other cattle breeds have similar physiological patterns of changing IGF1 concentrations. However, other cattle breeds show different patterns with increasing age because of physiological activities of other hormones influencing growth, as well as varying environmental effects such as diet.

\section{Genetic variants}

The bovine $I G F 1$ gene is located on chromosome 5 at nucleotide positions $66,532,877$ 66,604,734 (UMD_3.1, Chromosome, Bos taurus, Ensembl). The presence of cytosine-ade- 
nosine (CA) $)_{n}$ short tandem repeats (STR) in the promoter region has been reported using the rat and human $I G F-I$ gene (Rotwein et al., 1986). In addition, the STR marker located in the 5 '-flanking region of the bovine IGFI gene (Kirkpatrick, 1992) is widely used in analyses targeted towards the localization of quantitative and economically important traits (Curi et al., 2005). The distribution of alleles of STRs varied and depended on nucleotide diversities and inbreeding status of cattle breeds. A study reported that 3 alleles $(126,128$, and $130 \mathrm{bp})$ of STRs presented frequencies of 0.06, 0.68, and 0.26, respectively, in cattle (Kirkpatrick, 1992). However, we identified only 2 alleles, with frequencies of 0.604 and 0.396, in Hanwoo cattle, and similar findings were reported with frequencies of 0.74 and 0.26 for 2 alleles using Nellore cattle (Curi et al., 2005). In addition, 4 alleles were reported with frequencies of $0.11,0.26$, 0.56, and 0.07 in Canchim cattle (Machado et al., 2003).

Several studies found an SNP in the bovine 5' flanking region of the $I G F 1$ gene using an SnaBI restriction enzyme showing a $\mathrm{T}>\mathrm{C}$ transition located at a nucleotide position -472 (Ge et al., 1997; Parmentier et al., 1999). In addition, studies found genetic variants in either introns or the 5'-untranslated region (Ge et al., 2001; Li et al., 2004; Maj et al., 2008; Islam et al., 2009; Bonakdar et al., 2010; Reyna et al., 2010; Mullen et al., 2011) and in exon 1A (Edens and Talamantes, 1998). Several intronic variations have been reported in introns 3 (Kirkpatrick, 1993), 4 (TTTG insertion/deletion), and 5 (DpnI-RFLP) (Lien et al., 2000). Although several studies reported SNPs in the 5'-untranslated region, the SNP g.323C $>$ A identified in the present study has not been previously described in Hanwoo or other breeds of cattle.

\section{Association analysis}

The polymorphic microsatellite marker $(\mathrm{CA})_{\mathrm{n}}$ in the $I G F 1$ promoter region may explain genetic variations in animal growth; however, this is controversial according to several studies indicating that the STR marker contributes to the complexity of $I G F 1$ gene expression (Kirkpatrick, 1992; Moody et al., 1996; Machado et al., 2003; Curi et al., 2005). In addition, studies have shown that the marker is responsible for animal growth (Moody et al., 1996) and is associated with human circulating IGFI concentrations (Rosen et al., 1998). Although these studies reported significant associations between IGFI concentration and growth, one study suggested that the marker is not directly responsible for variation in growth traits (Machado et al., 2003). The present analysis also did not confirm that $I G F 1$ concentrations were significantly genetically correlated with animal growth. However, most studies have indicated that the polymorphism is associated with body weights and heights (Rietveld et al., 2004), although the results are inconsistent (Day et al., 2002). Thus, the effects of the STR marker in the 5 -untranslated region of $I G F 1$ is dependent on the breed of cattle involved, as well as environmental conditions, and therefore, more precise analyses with many individuals under various circumstances should be conducted.

Because the 7649-Da single-chain peptide appears to be associated with reproductive traits in Angus cattle (Yilmaz et al., 2004), we evaluated serum IGF1 concentrations and estimated allele and genotype frequencies of the bovine $I G F 1$ gene in Hanwoo cattle to determine the associations between polymorphisms and concentrations. Several studies reported that a genetic variant located in the first intron with an $S n a \mathrm{BI}$ restriction site was associated with milk fat, protein, body weight, subcutaneous backfat, and growth (Akis et al., 2010; Bonakdar et al., 2010; Reyna et al., 2010) in Holstein, East Anatolian, South Anatolian Red, and Mexican cattle. Particularly, a significant association between the SNP in the promoter region and carcass 
traits in hybrid, Angus, and Charolais cattle was observed (Islam et al., 2009). Furthermore, a study reported that a genetic variant was significantly associated with growth and carcass traits in Angus cattle, which was divergently selected according to the IGFI concentrations (Ge et al., 2001). In contrast, a significant association was not observed between the $I G F 1$ restriction fragment length polymorphism-SnaBI polymorphism and dairy production traits in Holstein cattle in a study by Hines et al. (1998). Although previous association studies were conducted to examine several traits, the relationship between $I G F 1$ concentration and genotypes has not been tested in beef cattle of widely distributed ages. Therefore, this analysis is the first report on the associations between genetic variants and blood serum IGF1 concentrations in Hanwoo cattle in various stages of growth. As shown in Table 2, the AA genotype presented extremely low IGF1 concentration compared to that by the other genotypes. Therefore, the findings in this analysis should be valuable regarding changes of genetic structures in beef populations to maximize economic benefits.

\section{Blood serum IGF1 concentration}

Although high genetic correlations have been reported for $I G F 1$ concentrations and animal growth, relatively little is known regarding the relationships between specific IGFI markers and IGFI concentrations in cattle. Associations between the IGFI gene and both $I G F 1$ expressions in the liver and IGFI concentration in the blood were reported in Polish Holstein-Friesian cattle (Maj et al., 2008). The authors reported that the highest IGF1 concentration in blood serum was found in animals with the homozygous CC genotype (1.024 ng/ $\mathrm{mL}$ ), whereas animals with genotypes TT and CT had IGFI concentrations of 698 and $859 \mathrm{ng} /$ $\mathrm{mL}$, respectively.

Eigenmann et al. (1984) observed a positive relationship between body size and circulating IGF1 concentrations in dogs and pigs. Comparison of macro- and miniature pigs revealed that macro-pigs contained higher IGFI concentrations (Buonomo et al., 1987). Siddiqui et al. (1990) also reported that a line of mice selected for 7 generations for high plasma IGFI concentrations showed $20 \%$ faster weight gain than a divergently selected low line. The present analysis confirmed that serum IGFI concentration significantly correlated with weight at 12 months of age, and IGFI concentration may be used to predict weight traits of Hanwoo cattle.

\section{CONCLUSIONS}

Discovery of polymorphic sites in the cattle genome using gene mapping procedures can help to identify genetic markers related to growth traits in order to maximize economic benefits with selection systems. Genotypes AC and CC of the $I G F 1$ gene exhibited significantly higher serum IGFI concentrations than those of genotype AA, reflecting an economically important candidate SNP that can be used in commercial settings to improve production rates of beef populations based on the significant relationship between IGFI concentration and animal growth. The present findings indicate that the identified genetic variants in the 5'-flanking region can be used in marker-assisted selection programs to improve weight traits according to the IGFI concentration. Consequently, the results of the present study and future genotypic data for beef cattle based on variations in the IGF1 gene will provide critical information for genetic improvement and will have a great impact on commercial markets when animal breeders select sires based on genotypes. 


\section{ACKNOWLEDGMENTS}

This study is part of the internal project "Cooperative Research Program for Agriculture Science \& Technology Development (\#PJ010220)" and was supported by the National Institute of Animal Science in Rural Development Administration of Korea.

\section{REFERENCES}

Akis I, Oztabak K, Gonulalp I, Mengi A, et al. (2010). IGF-1 and IGF-1r gene polymorphisms in East Anatolian Red and South Anatolian Red cattle breeds. Genetika 46: 497-501.

Anderson PT, Bergen WG, Merkel RA, Enright WJ, et al. (1988). The relationship between composition of gain and circulating hormones in growing beef bulls fed three dietary crude protein levels. J. Anim. Sci. 66: 3059-3067.

Bonakdar E, Rahmani HR, Edriss MA, Sayed Tabatabaei BE (2010). IGF-1 gene polymorphism, but not its blood concentration, is associated with milk fat and protein in Holstein dairy cows. Genet. Mol. Res. 9: 1726-1734.

Breier BH, Gluckman PD and Bass JJ (1988). Plasma concentrations of insulin-like growth factor-I and insulin in the infant calf: ontogeny and influence of altered nutrition. J. Endocrinol. 119: 43-50.

Buonomo FC, Lauterio TJ, Baile CA and Campion DR (1987). Determination of insulin-like growth factor 1 (IGF1) and IGF binding protein levels in swine. Domest. Anim. Endocrinol. 4: 23-31.

Curi RA, Oliveira HN, Silveira AC and Lopes CR (2005). Effects of polymorphic microsatellites in the regulatory region of IGF1 and GHR on growth and carcass traits in beef cattle. Anim. Genet. 36: 58-62.

Davis ME and Simmen RCM (1997). Genetic parameter estimates for serum insulin-like growth factor-I concentration and performance traits in Angus beef cattle. J. Anim. Sci. 75: 317-324.

Day IN, King TH, Chen XH, Voropanov AM, et al. (2002). Insulin-like growth factor-I genotype and birth weight. Lancet 360: $945-946$.

Edens A and Talamantes F (1998). Alternative processing of growth hormone receptor transcripts. Endocr. Rev. 19: 559-582.

Eigenmann JE, Patterson DF and Froesch ER (1984). Body size parallels insulin-like growth factor I levels but not growth hormone secretory capacity. Acta Endocrinol. 106: 448-453.

Fortier LA, Kornatowski MA, Mohammed HO, Jordan MT, et al. (2005). Age-related changes in serum insulin-like growth factor-I, insulin-like growth factor-I binding protein-3 and articular cartilage structure in Thoroughbred horses. Equine Vet. J. 37: 37-42.

Ge W, Davis ME and Hines HC (1997). Two SSCP alleles detected in the 5'-flanking region of bovine IGF1 gene. Anim. Genet. 28: 155-156.

Ge W, Davis ME, Hines HC, Irvin KM, et al. (2001). Association of a genetic marker with blood serum insulin-like growth factor-I concentration and growth traits in Angus cattle. J. Anim. Sci. 79: 1757-1762.

Goddard C, Wilkie RS and Dunn IC (1988). The relationship between insulin-like growth factor-1, growth hormone, thyroid hormones and insulin in chickens selected for growth. Domest. Anim. Endocrinol. 5: 165-176.

Hines HC, Ge W, Zhao Q and Davis ME (1998). Association of genetic markers in growth hormone and insulin-like growth factor I loci with lactation traits in Holsteins. Anim. Genet. 29: 69.

Islam KK, Vinsky M, Crews RE, Okine E, et al. (2009). Association analyses of a SNP in the promoter of IGF1 with fat deposition and carcass merit traits in hybrid, Angus and Charolais beef cattle. Anim. Genet. 40: 766-769.

Kirkpatrick BW (1992). Identification of a conserved microsatellite site in the porcine and bovine insulin-like growth factor-I gene 5'-flank. Anim. Genet. 23: 543-548.

Kirkpatrick BW (1993). Dialleic single-strand conformation polymorphism in the bovine insulin-like growth factor-1 third intron. Anim. Genet. 24: 144.

Li C, Basarab J, Snelling WM, Benkel B, et al. (2004). Assessment of positional candidate genes myf5 and igfl for growth on bovine chromosome 5 in commercial lines of Bos taurus. J. Anim. Sci. 82: 1-7.

Lien S, Karlsen A, Klemetsdal G, Våge DI, et al. (2000). A primary screen of the bovine genome for quantitative trait loci affecting twinning rate. Mamm. Genome 11: 877-882.

Lucy MC (2008). Functional differences in the growth hormone and insulin like growth factor axis in cattle and pigs: implications for post-partum nutrition and reproduction. Reprod. Domest. Anim. 43: 31-39.

Machado MBB, Alencar MM, Pereira AP, Oliveira HN, et al. (2003). QTL affecting body weight in a candidate region of cattle chromosome 5. Genet. Mol. Biol. 26: 259-265.

Maj A, Snochowski M, Siadkowska E, Rowinska B, et al. (2008). Polymorphism in genes of growth hormone receptor (GHR) and insulin-like growth factor-1 (IGF1) and its association with both the IGF1 expression in liver and its level 
in blood in Polish Holstein-Friesian cattle. Neuro. Endocrinol. Lett. 29: 981-989.

Malinowski K, Christensen RA, Hafs HD and Scanes CG (1996). Age and breed differences in thyroid hormones, insulinlike growth factor (IGF)-I and IGF binding proteins in female horses. J. Anim. Sci. 74: 1936-1942.

Moody DE, Pomp D, Newman S and MacNeil MD (1996). Characterization of DNA polymorphisms in three populations of Hereford cattle and their associations with growth and maternal EPD in line 1 Herefords. J. Anim. Sci. 74: 1784-1793.

Mullen MP, Lynch CO, Waters SM, Howard DJ, et al. (2011). Single nucleotide polymorphisms in the growth hormone and insulin-like growth factor-1 genes are associated with milk production, body condition score and fertility traits in dairy cows. Genet. Mol. Res. 10: 1819-1830.

NRC (2000). Nutrient Requirements of Beef Cattle. 6th edn. National Academy Press, Washington, DC.

Parmentier I, Portetelle D, Gengler N, Prandi A, et al. (1999). Candidate gene markers associated with somatotropic axis and milk selection. Domest. Anim. Endocrinol. 17: 139-148.

Reyna XF, Montoya HM, Castrellón VV, Rincón AM, et al. (2010). Polymorphisms in the IGF1 gene and their effect on growth traits in Mexican beef cattle. Genet. Mol. Res. 9: 875-883.

Rietveld I, Janssen JAMJL, van Rossum EFC, Houwing-Duistermaat JJ, et al. (2004). A polymorphic CA repeat in the IGF-I gene is associated with gender-specific differences in body height, but has no effect on the secular trend in body height. Clin. Endocrinol. 61: 195-203.

Roberts CA, McCutcheon SN, Blair HT, Gluckman PD, et al. (1990). Developmental patterns of plasma insulin-like growth factor-1 concentrations in sheep. Domest. Anim. Endocrinol. 7: 457-463.

Rosen CJ and Pollak M (1999). Circulating IGF-I: New Perspectives for a New Century. Trends Endocrinol. Metab. 10: 136-141.

Rosen CJ, Kurland ES, Vereault D, Adler RA, et al. (1998). Association between serum insulin growth factor-I (IGF-I) and a simple sequence repeat in IGF-I gene: implications for genetic studies of bone mineral density. J. Clin. Endocrinol. Metab. 83: 2286-2290.

Rotwein P, Pollock KM, Didier DK and Krivi GG (1986). Organization and sequence of the human insulin-like growth factor I gene. J. Biol. Chem. 261: 4828-4832.

Siddiqui RA, Blair HT, McCutcheon SN, Mackenzie DD, et al. (1990). Developmental patterns of plasma insulin-like growth factor-I (IGF-I) and body growth in mice from lines divergently selected on the basis of plasma IGF-I. $J$. Endocrinol. 124: 151-158.

Spicer LJ, Klindt J, Buonomo FC, Maurer R, et al. (1992). Effect of porcine somatotropin on number of granulosa cell luteinizing hormone/human chorionic gonadotropin receptors, oocyte viability, and concentrations of steroids and insulin-like growth factors I and II in follicular fluid of lean and obese gilts. J. Anim. Sci. 70: 3149-3157.

Staniar WB, Kronfeld DS, Akers RM and Harris PA (2007). Insulin-like growth factor I in growing thoroughbreds. $J$. Anim. Physiol. Anim. Nutr. 91: 390-399.

Wang J, Zhou J, Powell-Braxton L and Bondy C (1999). Effects of Igf1 gene deletion on postnatal growth patterns. Endocrinology 140: 3391-3394.

Yilmaz A, Davis ME and Simmen RC (2004). Estimation of (co)variance components for reproductive traits in Angus beef cattle divergently selected for blood serum IGF-I concentration. J. Anim. Sci. 82: 2285-2292. 